\title{
First record of Potamogetonaceae for the state of Rio Grande do Norte, Brazil
}

\author{
Henry-Silva, GG. ${ }^{a *}$, Moura, $R S T .^{a}$, Lopes, YVA. ${ }^{a}$ and Rodrigues, $R S .{ }^{b}$ \\ aUniversidade Federal Rural do Semi-Árido - UFERSA, Campus Mossoró, Avenida Francisco Mota, \\ 572, Costa e Silva, CEP 59625-900, Mossoró, RN, Brazil \\ ${ }^{\text {b}}$ Centro de Estudos da Biodiversidade, Universidade Federal de Roraima - UFRR, Av. Cap. Ene Garcez 2413, \\ Aeroporto, CEP 69310-000, Boa Vista, RR, Brazil \\ *e-mail: gustavo@ufersa.edu.br
}

Received: April 25, 2014 - Accepted: May 9, 2014 - Distributed: December 31, 2014

Potamogetonaceae is a small subcosmopolitan monocot family of aquatic herbs with submersed or floating leaves, belonging to the order Alismatales (Haynes and Holm-Nielsen, 2003). It is a taxonomically complex family (Kaplan et al., 2013), which may comprise three or more genera, depending on the including of Zannichelliaceae (Haynes and HolmNielsen, 2003; APGIII 2009; Kaplan et al., 2013).

Potamogeton is the largest genus of Potamogetonaceae, with ca. of 72 species (Kaplan et al., 2013), occurring mainly in temperate regions (Haynes and Holm-Nielsen, 2003). Some species of the genus are ecologically relevant as a source of food, shelter and reproduction site for several aquatic invertebrates and birds (Haynes, 1985).

In Brazil, Bove (2014a) recorded 12 species in three genera of Potamogetonaceae: Potamogeton, Stuckenia Börner and Zannichellia P. Micheli ex L. In the country, these three genera are found together only in the extreme south state of the Rio Grande do Sul (Bove, 2014a). On the other hand, Potamogeton is the only genus of Potamogetonaceae occuring in the tropical Northeast region of Brazil, with six species (Bove, 2014a). Nevertheless, to our knowledge, none species of Potamogeton has been cited for the state of Rio Grande do Norte (Rodrigues and Irgang, 2001; Haynes and Holm-Nielsen, 2003; Bove, 2014a, 2014b). As a part of a survey of the aquatic plants in the ApodiMossoró river basin (Henry-Silva et al., 2010), this work provides the first record of the Potamogetonaceae for the Rio Grande do Norte state.

Specimens were collected during expeditions in November 2013 to Santa Cruz reservoir, near the municipality of Apodi (0548'43.59" S; 03749'48.56” W). The specimens were deposited in the Herbarium of the Federal University of Roraima (code, UFRR). The identification of the specimens was based on Rodrigues and Irgang (2001) and Haynes and Holm-Nielsen (2003).

Material examined: BRAZIL. Rio Grande do Norte: Apodi, 25/XI/2013, fr., Henry-Silva s.n. (UFRR 3932).

Potamogeton pusillus can be easly recognized among Neotropical species with submersed leaves, free basal sheats and linear blades by the absence of keels in its fruits (Haynes and Holm-Nielsen, 2003). This species is early cosmopolitan and is represented in the Neotropics only by $P$. pusillus var. pusillus, where it extends from Mexico to Argentina (Haynes and Holm-Nielsen, 2003). It has been recorded for some states in all Brazilian regions, with the exception of the northern region (Bove, 2014a). In the Northeastern region, $P$. pusillus has been found in the states of Alagoas, Bahia, Ceará, Paraíba, Pernambuco (Bove, 2014a, b).

The record of P. pusillus in the Santa Cruz reservoir extends the known geographic distribution of this species, emphasing the importance of surveying the biodiversity of macrophytes in the state, especially in areas of the Biome Caatinga, where other taxa have been recently recorded (Henry-Silva et al., 2013). In addition, this study adds Potamogetonaceae to the Rio Grande do Norte flora, what is particularly significant since to the state Forzza et al. (2010) have registered the lowest number of flowering plant species among the 27 states of Brazil.

\section{Acknowledgments}

We thank the technician Luiz Carlos Fernandes for the assistance in field sampling; the Fundação de Amparo a Pesquisa do Estado do Rio Grande do Norte for the financial support on the research project; the Coordenação de Aperfeiçoamento de Pessoal de Nível Superior (CAPES) and to Conselho Nacional de Desenvolvimento Científico e Tecnológico $(\mathrm{CNPq})$ for the scholarships granted to the researches.

\section{References}

Angiosperm Phylogeny Group - APG III, 2009. An update of the Angiosperm Phylogeny Group classification for the orders and families of flowering plants: APG III. Botanical Journal of the Linnean Society, vol. 161, no. 2, p. 105-121. http://dx.doi. org/10.1111/j.1095-8339.2009.00996.x.

BOVE, CP., 2014a. Potamogetonaceae. Lista de Espécies da Flora do Brasil. Jardim Botânico do Rio de Janeiro. Available from: http://reflora.jbrj.gov.br/jabot/floradobrasil/FB199. Access in: 27 Jan 2014. 
BOVE, CP., 2014b. Potamogetonaceae. Checklist das Plantas do Nordeste (Version 1.5). Available from: http://www.cnip.org. br/bdpn/index.php. Access in: 26 Jan 2014

FORZZA, RC., BAUMGRATZ, JF., COSTA, A., HOPKINS, MJG., LEITMAN, P., LOHMANN, LG., MARTINELLI, G., MORIM, MP., COELHO, MN., PEIXOTO, AL., PIRANI, JR., QUEIROZ, LP., STEHMANN, J., WALTER, BMT. and ZAPPI, D., 2010. As angiospermas do Brasil. In FORZZA, RC., BAUMGRATZ, JF., BICUDO, CEM., CARVALHO JUNIOR, A., COSTA, A., COSTA, DP., HOPKINS, MJG., LEITMAN, P., LOHMANN, LG., MAIA, LC., MARTINELLI, G., MENEZES, M., MORIM, MP., COELHO, MN., PEIXOTO, AL., PIRANI, JR., PRADO, J., QUEIROZ, LP., SOUZA, VC., STEHMANN, J., SYLVESTRE, L., WALTER, BMT. and ZAPPI, D. Catálogo de plantas e fungos do Brasil. Rio de Janeiro: Andrea Jakobsson Estúdio/Jardim Botânico do Rio de Janeiro. p. 78-89.

HAYNES, RR. and HOLM-NIELSEN, LB., 2003. Potamogetonaceae. New York: The New York Botanical Garden. Flora Neotropica Monograph, vol. 85.
HAYNES, RR., 1985. A revision of the clasping-leaved Potamogeton (Potamogetonaceae). Sida, vol. 11, p. 173-188.

HENRY-SILVA, GG., MOURA, RST. and DANTAS, LLO., 2010. Richness and distribution of aquatic macrophytes in Brazilian semi-arid aquatic ecosystems. Acta Limnologica Brasiliensia, vol. 22, no. 2, p. 147-156. http://dx.doi.org/10.1590/S2179975X2010000200004.

HENRY-SILVA, GG., SANTOS, RV., MOURA, RST. and BUENO, NC., 2013. Primeiro registro de Chara indica e Chara zeylanica (Charophyceae, Charales, Characeae) em reservatórios do semiárido do estado do Rio Grande do Norte, Brasil. Biotemas, vol. 26, p. 243-248.

KAPLAN, Z., JAROLÍMOVÁ, V. and FEHRER, J., 2013. Revision of chromosome numbers of Potamogetonaceae: a new basis for taxonomic and evolutionary implications. Preslia, vol. 85 , p. 421-482.

RODRIGUES, RS. and IRGANG, BE., 2001. Potamogetonaceae Dumort. no Rio Grande do Sul, Brasil. Iheringia. Série Botânica, vol. 56, p. 3-49. 